Reprod. Nutr. Dévelop., 1984, 24 (6), 903-913.

\title{
ATP measurement in sheep rumen digesta using dimethyl sulfoxide as an extraction reagent
}

\author{
Sylvie KOMISARCZUK, Michelle DURAND, Geneviève HANNEQUART
}

Station de Recherches de Nutrition, I.N.R.A. 78350 Jouy-en-Josas, France.

Summary. Dimethyl sulfoxide (DMSO) has been used to extract adenosine ${ }^{\prime}$ triphosphate (ATP) from the rumen contents of sheep fed with three different diets : beet pulp, semipurified and grass-hay.

After having determined the conditions for the utilization of DMSO (extraction within 15 min after sampling, storage of extracts at $0^{\circ} \mathrm{C}$ and immediate assay or deep-freezing in liquid nitrogen and storage at $-80^{\circ} \mathrm{C}$ ), this extractant was compared to cold $\mathrm{H}_{2} \mathrm{SO}_{4} 0.6 \mathrm{~N}$; NRB (Lumac) and Nucleoline (CLV Interbio). DMSO proved to be more efficient than the other three extractants. The relative effectiveness of sulfuric acid, compared to DMSO, was a mean of about $80 \%$, while that of NRB was $30 \%$ and that of Nucleoline $8 \%$ with wide inter-dietary variations. The new method developed can be applied to the study of ATP in in vitro systems.

\section{Introduction.}

Adenosine $5^{\prime}$ triphosphate (ATP), the main molecule of energy transport in microbial cells, has been used as an indicator of metabolic activity in a number of living microorganisms in biological ecosystems such as water, soil, activated sludges and food (Holm-Hansen and Booth, 1966; Levin, Cheng and Davis, 1967; Touzel and Morfaux, 1979; Lacheretz, 1978 ; Sharpe, Woodrow and Jackson, 1970 ; Tobin, Ryan and Afghan, 1978). It would be useful to have a precise and easy method for extracting and measuring ATP in rumen fluid in order to better understand certain aspects of fermentation and metabolism as, for example, in special cases of feeding which result in energetic uncoupling and decrease in microbial yield $\left(Y_{\text {ATP }}\right)$. Only a few authors have measured ATP concentrations in the rumen as indicators of its metabolic activity (Wolstrup and Jensen, 1976, 1978 ; Wolstrup, Jensen and Just, 1979 ; Forsberg and Lam, 1977 ; Wallace and West, 1982 ; Erfle, Mahadevan and Sauer, 1981 ; Nuzback et al., 1983). 
The luciferin-luciferase bioluminescent system of fireflies (Photinus pyralis) (McElroy, 1947) gives an exact and very sensitive measurement of ATP concentrations. This method has been used successfully in rumen fluid (Forsberg and Lam, 1977 ; Wallace and West, 1982 ; Wolstrup, Jensen and Just, 1979). However, the first step of analysis, the ATP extraction, must be very reliable and simple. Forsberg and Lam (1977) compared six different methods of extraction and obtained the best results using cold $0.6 \mathrm{~N} \mathrm{H}_{2} \mathrm{SO}_{4}$ as the reagent which was found to extract twice as much ATP as the boiling tris buffer recently used by Nuzback et al. (1983). Wallace and West (1982) confirmed the efficiency of the $\mathrm{H}_{2} \mathrm{SO}_{4}$ technique, but even simplified, this procedure remains time-consuming and therefore is not suitable for routine measurements.

Other authors (Jakubczak and Leclerc, 1981; Komisarczuk et al, unpublished) advocated the use of dimethyl sulfoxide (DMSO) because it is easy and efficient to employ, but they worked with pure cultures of non-rumen bacteria.

The objectives of the present work were first to examine the use of DMSO as a suitable extractant of ATP in rumen fluid and to study the stability of ATP in stored extracts and, second, to compare the use of DMSO with cold $0.6 \mathrm{~N} \mathrm{H}_{2} \mathrm{SO}_{4}$ and two commercial reagents, NRB ( $\left.{ }^{1}\right)$ and Nucleoline $\left({ }^{2}\right)$. The studies were conducted on sheep fed three different diets : beet pulp, semi-purified and grasshay.

\section{Material and methods.}

\section{Animals and diets.}

Eight adult lle-de-France sheep, averaging $70 \mathrm{~kg}$ each and each fitted with a permanent rumen cannula, were fed twice daily (table I) with one of the three following diets : beet pulp concentrate ( 3 sheep), semi-purified ( 3 sheep) or grasshay (2 sheep). The first two groups were given daily $1.1 \mathrm{~kg}$ of each feed plus $0.1 \mathrm{~kg}$ of barley straw. The third group received grass-hay ad libitum plus $0.1 \mathrm{~kg}$ of beet pulp concentrate. Diet composition is given on table 1. The sheep were adapted to the diets for at least 3 weeks before sampling began.

TABLE 1

Composition of diets $\{\mathrm{g} / \mathrm{kg} \mathrm{DM}\}$

\begin{tabular}{|c|c|c|c|}
\hline \multicolumn{2}{|l|}{ Semi-purified diet } & \multicolumn{2}{|l|}{ Beet pulp concentrate diet } \\
\hline Maize starch & 370 & Beet puip & 534 \\
\hline Cellulose ... & 260 & Cassava . . & 333 \\
\hline Cerelose ... & 250 & Urea .... & 45 \\
\hline Urea ........... & 40 & Maize oil . . . . . . . & 30 \\
\hline Mineral supplement . & 50 & Mineral supplement . . . . . . . . . . . . . . & 12 \\
\hline Maize oil . . . . . . . . & 30 & & \\
\hline
\end{tabular}

(1) NRB : Lumac-LPM, 40, rue Gabriel-Crié, Malakoff, France.

(2) Nucleoline : C.L.V. Interbio, 34, rue Maurice-Berteaux, Le Tiliay, France. 
Samples of rumen fluid were taken $2 \mathrm{~h}$ after feeding via the cannula using a vacuum pump and then transferred immediately into an isothermal flask; the fluid, filtered through two layers of surgical gauze, was kept at room temperature and gassed with $\mathrm{CO}_{2}$.

\section{Extraction of adenosine nucleotide.}

a) Dimethyl sulfoxide (DMSO).

Rumen fluid sample. - One milliliter of filtered rumen fluid was first mixed vigorously with $9 \mathrm{ml}$ of pure DMSO for $15 \mathrm{sec}$ with a Vortex and then left to rest for $2 \mathrm{~min}$ at room temperature. Immediately afterwards $5 \mathrm{ml}$ of $10^{-2} \mathrm{M}$ morpholinopropionic sulfonic acid (MOPS) buffer containing $10^{-3} \mathrm{M}$ of EDTA was added to $1 \mathrm{ml}$ of the rumen extract. The extract was then rapidly analysed for ATP or frozen at $-20^{\circ} \mathrm{C}$ or $-80^{\circ} \mathrm{C}$ until assay. The effects of temperature and length of storage on the ATP concentration were determined.

Feed samples. - Ten grams of feed were weighed in a beaker and $90 \mathrm{ml}$ of DMSO were added. The mixture was agitated by hand for $2 \mathrm{~min}$ and then left to rest for $1 \mathrm{~min}$ before being filtered through filter paper. One $\mathrm{ml}$ of filtrate was mixed with $5 \mathrm{ml}$ of MOPS buffer as for rumen fluid samples.

b) Cold $0.6 \mathrm{~N} \mathrm{H}_{2} \mathrm{SO}_{4}$. - A procedure similar to that described by Wallace and West (1982) was used. Five $\mathrm{ml}$ of ice-cold $0.6 \mathrm{~N} \mathrm{H}_{2} \mathrm{SO}_{4}$ were added to $5 \mathrm{ml}$ of filtered rumen fluid in a stainless steel centrifuge tube. The tubes were stoppered, mixed for $15 \mathrm{sec}$ with a Vortex and maintained in an ice-bath for $3 \mathrm{~min}$; they were then centrifuged at $30,000 \times \mathrm{g}$ at $4{ }^{\circ} \mathrm{C}$ for $10 \mathrm{~min}$. ATP was assayed after the extract was neutralized by adding $2 \mathrm{ml}$ of supernatant and $1 \mathrm{ml}$ of $1 \mathrm{~N} \mathrm{NaOH}$, $2 \mathrm{ml}$ of $1 \mathrm{M}$ Tris- $\mathrm{HCl}$ buffer, $\mathrm{pH} 7.8$, and $5 \mathrm{ml}$ of deionized water. At this stage, the $\mathrm{pH}$ must be between 7 and 8 , and the neutralizing step must take less than $15 \mathrm{~min}$. Neutralized extracts were stored on ice until analysis.

c) Commercial reagents. - NRB (Lumac) and Nucleoline (CLV Interbio) were used according to the same procedure : $1 \mathrm{ml}$ of filtered rumen fluid was agitated by hand with $1 \mathrm{ml}$ of reagent for 20 to $30 \mathrm{sec}$; immediately before analysis the extracts were diluted $1 / 100$ or $1 / 1,000$ with deionized water, depending on their ATP concentration.

\section{Measurement of ATP.}

After extraction, ATP was measured by the luciferin-luciferase system with LKB reagents and a 1,250 LKB Luminometer. Linearity of response was observed between 50 and 2,000 arbitrary luminous units, namely between $10^{-4}$ and $10^{-1} \mu \mathrm{g}$ ATP/assay. This range corresponded to the lowest coefficient of variation $(4 \%)$.

The procedure is described on figure 1 . The ATP standard solution was prepared by diluting ATP with $1.6 .10^{-2} \mathrm{M} \mathrm{MgSO}_{4} 7 \mathrm{H}_{2} \mathrm{O}$ and the $1 \%$ stock solution was kept frozen. Further dilution was carried out in deionized water. The ATP standard was assayed after addition to the extracts so as to avoid any possible inhibition due to the extraction procedure or to the sample itself. ATP concentration has been computed on figure 1 . The average value of the light emitted ( $\mathrm{A}$ or $\mathrm{B})$ over the first $5 \mathrm{sec}$ has been taken into account. 


\section{EXTRACTS}

First series of measurements :

Second series of measurements : sample only (in triplicate) sample plus ATP standard (in triplicate)

$100 \mu \mathrm{l}$ extract

$350 \mu \mathrm{l} \mathrm{H}_{2} \mathrm{O}$

$50 \mu$ of monitoring ATP reagent

$100 \mu \mathrm{l}$ extract

$340 \mu \mathrm{l} \mathrm{H}_{2} \mathrm{O}$

$10 \mu \mathrm{l}$ ATP standard solution

$50 \mu \mathrm{l}$ monitoring ATP reagent

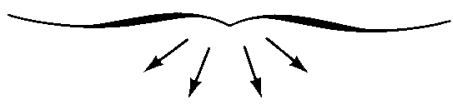

Emitted light $A$

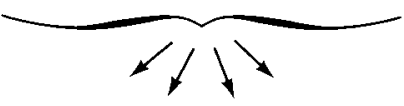

Emitted light $\mathrm{B}$

$$
\text { Calculation : } \mathrm{Q}=\frac{\mathrm{A}}{(\mathrm{B}-\mathrm{A})} \times \mathrm{d} \times \mathrm{E}
$$

$\mathrm{Q}$ : ATP concentration (mg/l of rumen fluid) ; $\mathrm{d}$ : dilution factor ; $\mathrm{E}$ : quantity of standard ATP added to the sample $(\mathrm{mg})$.

(The concentration of the internal standard was about twice that of the samples).

FIG. 1. - Bioluminescence procedure for measuring ATP in rumen extracts.

\section{Results.}

\section{Extraction procedure with DMSO.}

Sample storage before extraction. - The optimal conditions for ATP storage in rumen fluid were studied using samples from sheep fed with the three different diets. The results obtained after storage at room temperature under $\mathrm{CO}_{2}$ for various times up to $2 \mathrm{~h}$ are presented in table 2 .

TABLE 2

Evolution of ATP pool in rumen fluid samples $(\mathrm{mg} / \mathrm{l})$ after storage at room temperature and under $\mathrm{CO}_{2}$ (Samples were taken two hours after feeding) $\mathrm{m} \pm \mathrm{SE} ; \mathrm{n}=3$.

\begin{tabular}{clll}
\hline $\begin{array}{c}\text { Time after } \\
\text { extraction } \\
\text { (min) }\end{array}$ & Beet pulp diet & Semi-purified diet & Hay diet \\
\hline 0 & $212 \pm 11^{\mathrm{a}}$ & $39.8 \pm 3^{\mathrm{a}}$ & $35.7 \pm 5.3^{\mathrm{a}}$ \\
15 & $210 \pm 24^{\mathrm{a}}$ & $38.2 \pm 0.8^{\mathrm{a}}$ & $33 \pm 1.6^{\mathrm{a}}$ \\
30 & $200 \pm 7^{\mathrm{a}}$ & $36.4 \pm 2^{\mathrm{a}}$ & $27.6 \pm 3.8^{\mathrm{a}}$ \\
60 & $197 \pm 13^{\mathrm{a}}$ & $33 \pm 4^{\mathrm{b}}$ & $24.7 \pm 2^{\mathrm{b}}$ \\
90 & $177 \pm 10^{\mathrm{b}}$ & $32.6 \pm 0.3^{\mathrm{b}}$ & 22 \\
120 & $151 \pm 1.4^{\mathrm{c}}$ & $26.7 \pm 1.4^{\mathrm{c}}$ & \\
\hline
\end{tabular}

a, b, $c$ : values within the same column with different superscript differ significantly: $a \neq b: p<0.05 ; a \neq c, b \neq c: p<0.01$. 
There was no significant loss of ATP during the first $15 \mathrm{~min}$. During the following $15 \mathrm{~min}$, ATP content decreased by 6,8 and $22 \%$ for beet pulp, semipurified and grass-hay diets, respectively. Further significant losses occurred in all samples over the rest of the $2 \mathrm{~h}$ period. Therefore, ATP has to be extracted rapidly within the first 15 min after sampling.

Extract storage. - For this study, only sheep fed the beet pulp diet were used. The maximal storage time was tested (1) at room temperature $\left(+20^{\circ} \mathrm{C}\right)$ and in ice $\left(0^{\circ} \mathrm{C}\right)$ during the first $3 \mathrm{~h}$ following extraction and (2) after freezing at $-20^{\circ} \mathrm{C}$ or $-80^{\circ} \mathrm{C}$ during 80 days. Freezing during $5 \mathrm{~min}$ in liquid nitrogen before storage during $24 \mathrm{~h}$ at $-80^{\circ} \mathrm{C}$ was also tested. To determine ATP concentrations, the extracts after thawing at room temperature, were kept on ice and assayed within $1 \mathrm{~h}$.

(1) During the first $3 \mathrm{~h}$ following extraction (fig. 2), ATP disappeared rapidly in samples stored at $+20^{\circ} \mathrm{C}$. There was a $27 \%$ loss 15 min after extraction. After $1 \mathrm{~h}$, the quantity of ATP in the extract stabilized at $67 \%$ of the initial value. On the other hand, at $0{ }^{\circ} \mathrm{C}$ the loss within the first hour of storage was not significant. Theoretically, DMSO should inhibit intracellular ATPases and transphosphorilases. However, enzymatic activity in DMSO extracts was not inhibited, if the samples were stored at $+20^{\circ} \mathrm{C}$. The inhibitory effect of DMSO had to be combined with that of cold to allow satisfactory storage of ATP within the first hour after extraction.

(2) Upon freezing at $-20^{\circ} \mathrm{C}$, the ATP content decreased by 30, 42 and $92 \%$ after 20,30 and 80 days, respectively (fig. 3 ). At $-80^{\circ} \mathrm{C}$, there was only a $14 \%$ loss after 30 days and $25 \%$ after 80 days. But, if the samples were immediately frozen in liquid nitrogen before storage at $-80^{\circ} \mathrm{C}$, the ATP was better conserved during 24 hours (180 \pm 2 VS $172 \pm 5 \mathrm{mg} / \mathrm{l})$.

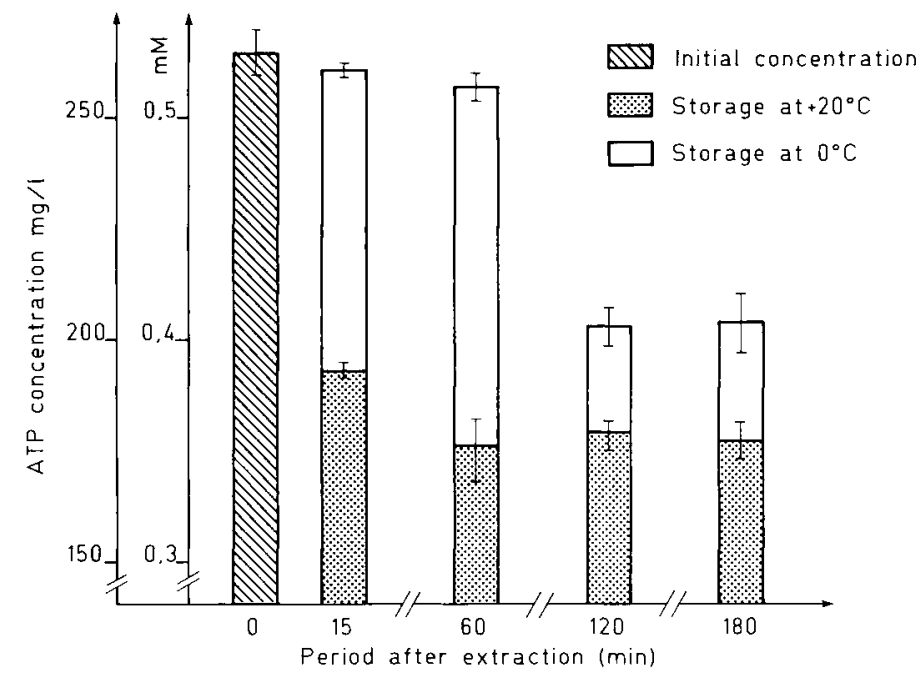

FIG. 2. - Short-term conservation of ATP in DMSO extracts at $+20^{\circ} \mathrm{C}$ or at $0^{\circ} \mathrm{C}$ $(\mathrm{m} \pm \mathrm{SE} ; \mathrm{n}=3)$. 


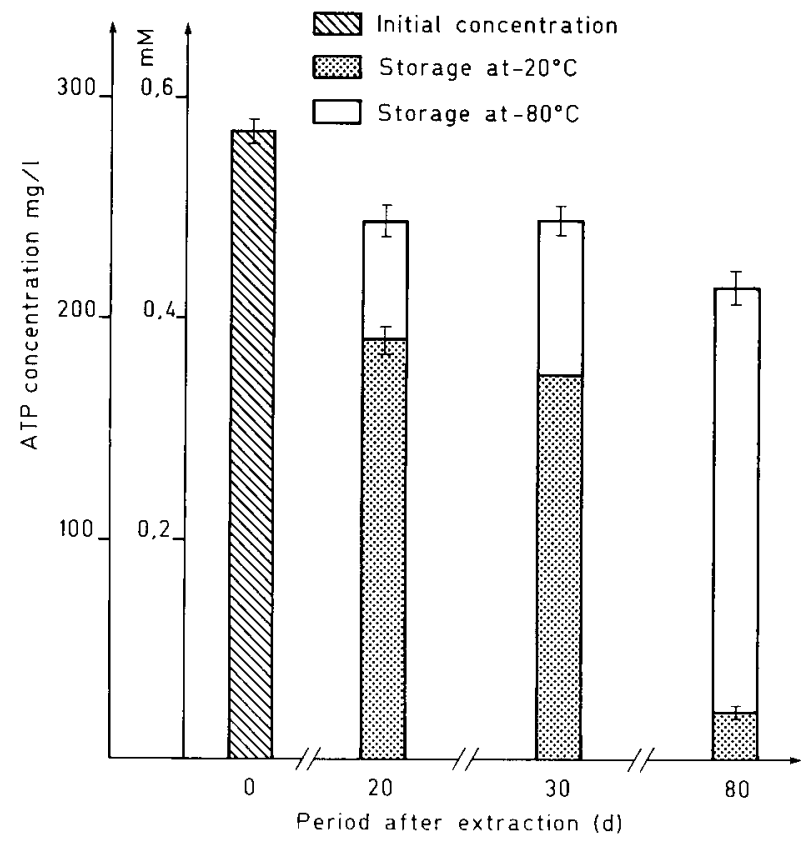

FIG. 3. - Long-term conservation of ATP in DMSO extracts after storage at $-20^{\circ} \mathrm{C}$ or at $-80^{\circ} \mathrm{C}$ $(\mathrm{m} \pm \mathrm{SE} ; \mathrm{n}=3)$.

Reproducibility of extraction. - In the extraction procedure used by Jakubczak and Leclerc (1981) for pure culture of bacteria, only $0.1 \mathrm{ml}$ of the sample was utilized. However, the viscosity of the filtered rumen fluid samples, especially with the beet pulp diet, was such that at least $1 \mathrm{ml}$ had to be analysed.

To test whether the variability of the results depended on sample ATP concentration, a relationship was established between the mean ATP value in the three extractions and their standard error (fig. 4). When ATP concentrations were less than $100 \mathrm{mg} / \mathrm{l}$, as with the semi-purified and grass-hay diets, variability increased linearly with the concentration ( $r=0.97$ and $C V=4 \%$ ). With higher ATP concentrations (150-300 mg/l), similar to those generally obtained with the beet pulp diet, the regression coefficient was lower $(0.80)$, indicating a higher variability ( $\mathrm{CV}=6 \%$ ) as the concentration increased; this could be due to the high ratio of ATP concentration over the amount of DMSO in the extract. Therefore, it might be advisable to increase the quantity of DMSO utilized relative to ATP concentration (e.g. $18 \mathrm{ml}$ of pure DMSO instead of $9 \mathrm{ml} / 1 \mathrm{ml}$ of sample). We attempted to reduce ATP concentration by diluting the sample with physiological saline, artificial saliva or deionized water before extraction, but the results were not satisfactory : losses of 30 to $80 \%$ were found after dilution.

Transmission electronic microscopy of the bacterial extract by DMSO. - A rumen bacterial sediment has been extracted with DMSO and then submitted to 


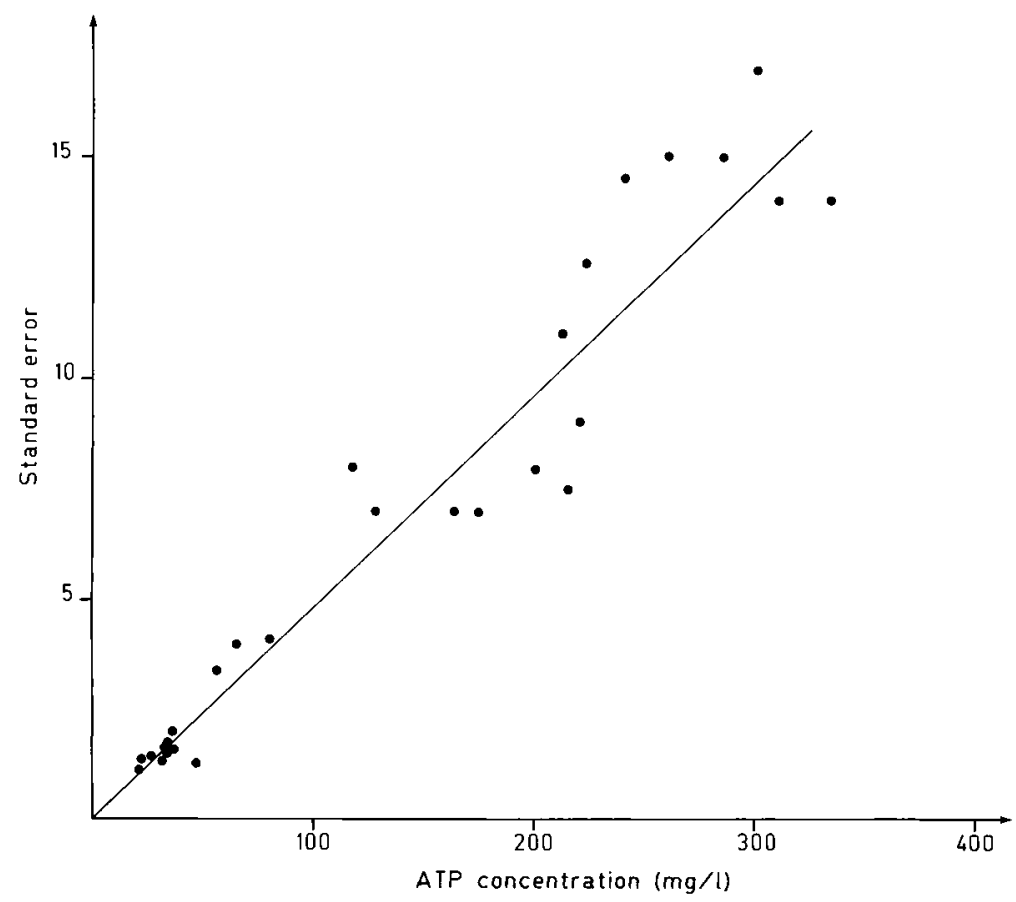

FIG. 4. - Relationship between mean ATP concentrations of 3 DMSO extracts and standard error.

T.E.M. Comparison of micrographs 1 and 2 (fig. 5) show that DMSO extraction induces a cytoplasmic aggregation and destabilizes membranes allowing the cytoplasmic compounds to be released in the medium.

\section{Comparison of extraction procedures.}

The efficiency of cold $0.6 \mathrm{~N} \mathrm{H}_{2} \mathrm{SO}_{4}$, NRB and Nucleoline has been compared to that of DMSO (fig. 5). With all three diets, the extraction of ATP with $\mathrm{H}_{2} \mathrm{SO}_{4}$ was about $80 \%$ of that obtained with DMSO.

The relative efficiency of NRB varied with the type of diet : the extracted ATP was about 30,10 and $40 \%$ of the values obtained with DMSO for beetpulp, grass-hay and semi-purified diets respectively.

The non-specific extract reagent Nucleoline was totally inefficient with anaerobic microorganisms (about $8 \%$ of that of DMSO).

\section{Effect of diet on ATP concentration in rumen fluid.}

Large variations in ATP concentration were observed in rumen fluid from sheep fed with the different diets whatever the extraction procedure (fig. 6). Following DMSO extraction an average concentration of $240 \mathrm{mg} /$ liter of filtered fluid was found with the beet pulp diet and 40 and $21 \mathrm{mg}$ with the grass-hay and the semi-purified diets respectively. 


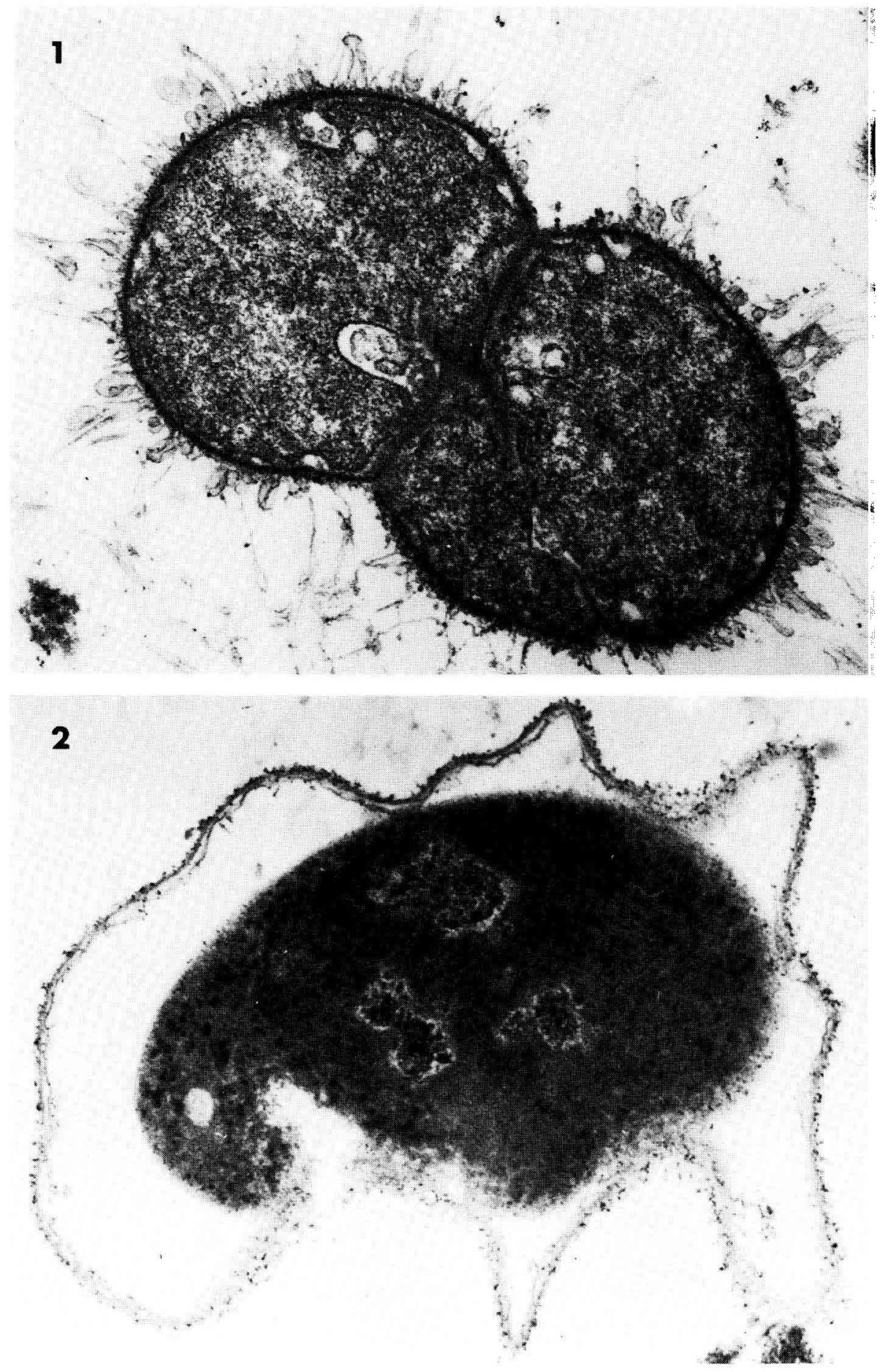

FIG. 5. - TEM of rumen bacteria without (1) $(\times 44,000)$ and with (2) $(\times 28,600)$ DMSO treatment. 


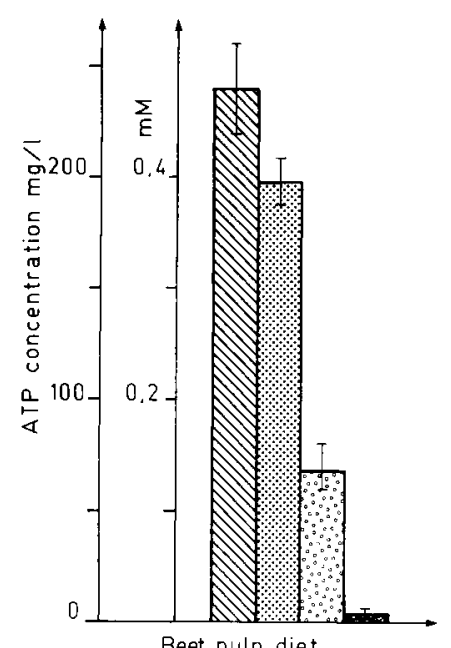

Beet pulp diet

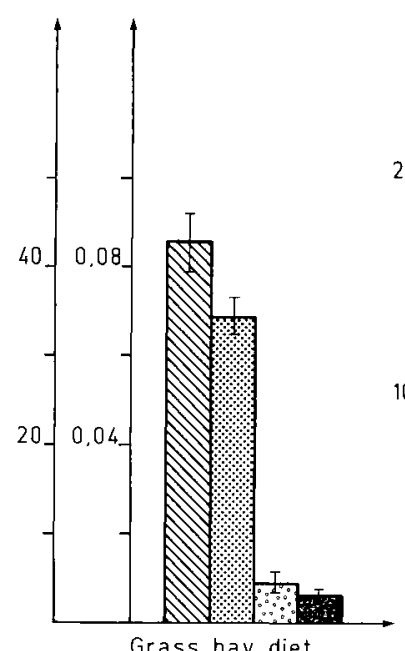

Grass hay diet

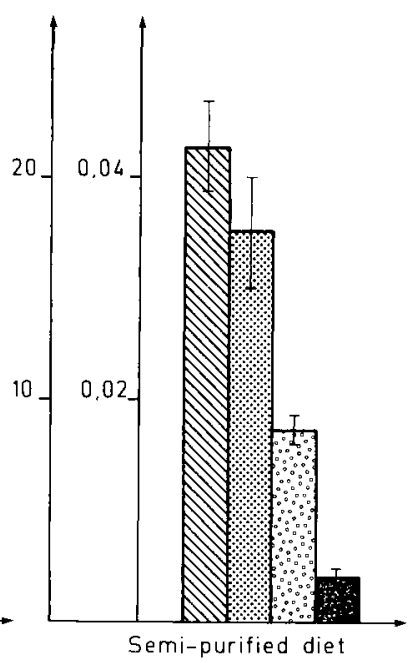

Semi-purified diet

$\begin{array}{ll}\text { DIJ DMSO } & \text { NRB } \\ \text { Cold } 0.6 \mathrm{NH}_{2} \mathrm{SO}_{4} & \text { Nucleoline }\end{array}$

FIG. 6. - Comparison of ATP extraction procedures with the three different diets $(\mathrm{m} \pm \mathrm{SE} ; \mathrm{n}=3)$.

\section{Discussion.}

Different methods of extracting ATP from rumen fluid have been studied previously (Forsberg and Lam, 1977 ; Erfle et al., 1979) with both groups of workers reporting $\mathrm{H}_{2} \mathrm{SO}_{4}$ as the most efficient extractant of those examined. In the present experiments, although we also found $\mathrm{H}_{2} \mathrm{SO}_{4}$ to be a good extractant of ATP from rumen fluid, we found that DMSO consistently extracted greater (approximately $20 \%$ ) amounts of ATP. These results agree with observations by Jakubczak and Leclerc (1981) that, with different pure isolates of non-rumen bacteria, $\mathrm{H}_{2} \mathrm{SO}_{4}$ was always less efficient in extracting ATP than DMSO, with large variations depending on the species of bacteria. Extraction of ATP with $\mathrm{H}_{2} \mathrm{SO}_{4}$ requires a series of manipulations to be performed within a short time (15 min, Wallace and West, 1982) whereas extraction with DMSO is considerably simpler and much quicker, but because of its possible skin toxicity suitable precautions must be taken.

The large variations reported here in ATP concentrations observed in rumen fluid of sheep receiving different diets have also been reported for sheep (Wallace and West, 1982) and cows (Erfle et al., 1979, 1981).

This variation has been related to the digestibility of the diet (Wolstrup and Jensen, 1976 ; Forsberg and Lam, 1977 ; Wallace and West, 1982) and in the present work rumen ATP level was the highest with the beet pulp diet which gives a high rate of fermentation (Durand et al., unpublished results). 
Protozoa have been shown to contain approximately ten times as much ATP as bacteria (Forsberg and Lam, 1977), and in the rumen, protozoa can constitute as much as $75 \%$ of the total ATP present (Wallace and West, 1982). The differences observed in rumen ATP content can reflect the effect of diet on the size of the protozoal population, which may explain, at least in part, the poor and variable efficiencies of extraction of ATP by NRB reagent which is considered to be a specific extractant for bacteria.

\section{Conclusion.}

In samples as heterogeneous and anaerobic as rumen contents, DMSO extraction capacity was better than that of commonly used reagents such as $\mathrm{H}_{2} \mathrm{SO}_{4}$. In addition, the simplicity of the procedure allowed easier routine measurement than cold $\mathrm{H}_{2} \mathrm{SO}_{4}$.

The present method can be used to study the evolution of ATP pools in in vitro systems, where the homogeneity of the fluid can be more easily controlled than in vivo and where ATP pools are smaller than in in vivo conditions. The yield of rumen microbial growth in different nutritional conditions and the correlation between VFA production and ATP concentration remain to be determined.

To apply the use of DMSO to in vivo microbial metabolism in the rumen, it is necessary to determine the concentration of ATP in the different fractions of rumen contents.

Recu en janvier 1984. Accepté en juillet 1984.

Acknowledgments. - The authors thank Dr Brian Brooker and Miss Kaven Wells of the National Institute of Research in Dairying (Reading, England) for the electron microscopy studies.

Résumé. Utilisation du diméthyl sulfoxide comme agent d'extraction pour la mesure de I'ATP des contenus de rumen de mouton.

Le diméthyl sulfoxyde (DMSO) a été utilisé comme agent d'extraction de I'ATP dans les contenus de rumen de moutons nourris avec 3 régimes différents (pulpes de betterave, semi-synthétique et foin).

Après avoir précisé les conditions d'utilisation de ce réactif (extraction dans les 15 min suivant le prélèvement, conservation des extraits à $0^{\circ} \mathrm{C}$ et dosages dès la première heure, ou congélation dans l'azote liquide et conservation à $-80^{\circ} \mathrm{C}$ ) nous I'avons comparé aux agents d'extraction suivants: $\mathrm{H}_{2} \mathrm{SO}_{4} 0,6 \mathrm{~N}$ à froid, NRB (Lumac) et Nucléoline (CLV Interbiol. Le DMSO s'est révélé plus efficace que ces trois autres agents. Par rapport au DMSO, l'efficacité relative de l'acide sulfurique est en moyenne d'environ $80 \%$, celle du NRB de $30 \%$, celle de la nucléoline de $8 \%$ avec de grandes variations inter-régimes. La méthode mise au point peut dès à présent être appliquée à l'étude de la production d'ATP dans les fermenteurs in vitro. 


\section{References}

ERFLE J. D., MAHADEVAN S., SAUER F. D., 1979. Effect of diet quality on ATP concentration and adenylate energy charge of rumen microbes from fistulated cows. J. Dairy Sci, 62, 284-291.

ERFLE J. D., MAHADEVAN S., SAUER F. D., 1981. Relationship between adenylate energy charge, rumen volatile fatty acid concentrations, and rates of production and dry matter digestibility in the cow. J. Dairy Sci., 64, 634-642.

FORSBERG C. W., LAM K., 1977. Use of adenosine $5^{\prime}$ triphosphate as an indicator of the microbiota biomass in rumen contents. Appl, environ. Microbiol., 33, 528-537.

HOLM-HANSEN O., BOOTH C. R., 1966. The measurement of ATP in the ocean and its ecological significance. Limnol., Oceanogr., 11, 510-519.

JAKUBCZAK E., LECLERC H., 1981. Mesure de I'ATP bactérien par bioluminescence. Etude critique des méthodes d'extraction. Ann. Biol. clin., 38, 287-304.

LACHERETZ A. P., 1978. Essai de détermination de la contamination bactérienne des denrées alimentaires par mesure de l'ATP. Th. Doct. Vét. Univ. Paul Sabatier, Toulouse, $102 \mathrm{p}$.

LEVIN G. V., CHENG G. S., DAVIS E., 1967. Development of the firefly bioluminescence assay for the rapid quantitative detection of microbial contamination in water. Aerospace med. Res. Lab., TR 67-71.

McELROY W. D., 1947. The energy source for bioluminescence in an isolated system. Proc. nat. Acad. Sci., USA, 33, 342-345.

NUZBACK D. E., BARTLEY E. E., DENNIS S. M., NAGARAJA T. G., GALITZER S. J., DAYTON A. D., 1983. Relation of rumen ATP concentration to bacterial and protozoal numbers. Appl. environ. Microbiol., 46, 533-538.

SHARPE A. N., WOODROW M. N., JACKSON A. K., 1970. Adenosine 5'-triphosphate (ATP) level in food contamined with bacteria. J. appl. Bacteriol., 33, 758-767.

TOBIN R. S., RYAN J. F., AFGHAN B. K., 1978. An improved method for the determination of adenosine $5^{\prime}$-triphosphate in environmental samples. Water Res., 12, 738-792.

TOUZEL J. D., MORFAUX J. N., 1979. Mesure de l'ATP des boues activées. Validité et limite en épuration biologique. La Tribune du Cebedeau, 433, 481-492.

WALLACE R. J., WEST A. A., 1982. Adenosine 5'-triphosphate and adenylate energy charge in sheep digesta. J. agric. Sci. Camb., 98, 523-528.

WOLSTRUP J., JENSEN K., 1976. Adenosine triphosphate in the bovine rumen during maximum nutrient supply and starvation. J. appl. Bacteriol., 41, 243-250.

WOLSTRUP J., JENSEN K., 1978. Adenosine triphosphate and deoxyribonucleic acid in the alimentary tract of cattle fed different nitrogen sources. J. appl. Bacteriol., 95, 49-56.

WOLSTRUP J., JENSEN K., JUST A., 1979. ATP and DNA as microbial parameters in the alimentary tract. Ann. Rech. vet., 10, 283-285. 